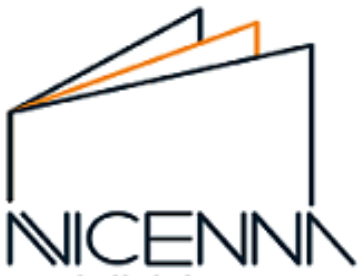

publishing $\mathrm{co}$.

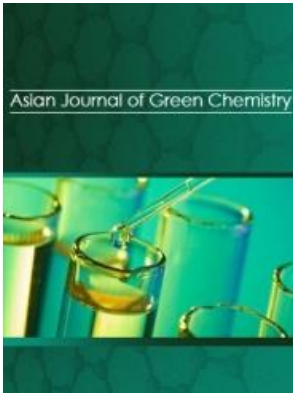

Original Research Article

\title{
An efficient approach to the synthesis of some novel heterocycles related to indoline moiety using [BMIm]Cl catalysis
}

\section{Leila Youseftabar-Miri, ${ }^{\mathrm{a}, *}$, Hamide Hosseinjani-Pirdehi ${ }^{\mathrm{b}}$}

a Department of Chemistry, Tehran Medical Sciences Branch, Islamic Azad University, Tehran, Iran

b Department of Chemistry, Tarbiat Modares University, P.O. BOX, 14115-175, Tehran, Iran

\section{ARTICLE INFORMATION}

Received: 15 July 2017

Received in revised: 25 July 2017

Accepted: 8 August 2017

Available online: 24 August 2017

DOI: 10.22631/ajgc.2017.95721.1017

\section{KEYWORDS}

Ionic liquid

Multi-compound reactions

Spirooxindole

Isatin

Pyrazole

\section{ABSTRACT}

The combination of isatins, active methylene reagents and 4phenylurazole/ phthalhydrazide in the presence of ionic liquid $([\mathrm{BMIm}] \mathrm{Cl})$ as a solvent catalyst was found to be a suitable and efficient method for the synthesis of the biologically important spirooxindoles. The features of this procedure were characterized by one-pot procedure, reasonable reaction times, fairly high yields, and simple isolation procedures. The ionic liquid can be easily separated and reused for several times.

\section{Graphical Abstract}<smiles>[R]c1ccc2c(c1)C(=O)C(=O)N2</smiles>

(1a-e)<smiles>[R2]C[NH+]</smiles>

(2a-b)<smiles>CCC(=O)NNC(=O)C(C)CC</smiles>

(3a-b)
[BMIm]Cl $90^{\circ} \mathrm{C}$<smiles>[R]C1=C(N)n2c(=O)n(-c3ccccc3)c(=O)n2C12C(=O)Nc1ccc([R])cc12</smiles>

(4a-k) 


\section{Introduction}

Modern synthesis design demands high efficiency in terms of minimization of synthetic steps together with maximization of complexity [1]. To meet these goals, chemists have been attempting specially to develop multi-component reactions (MCRs) [2]. The MCRs strategy offers significant advantages over conventional liner-type synthesis due to its flexible, convergent, and atom efficient nature [2-4]. In this view, designing MCRs without using toxic catalysts in solvent-free conditions as well as in recyclable solvents such as ionic liquids is particularly worthwhile for complementing the significant characters of MCRs, so as to satisfy the green chemistry's principles [5].

Recently, using ionic liquids (ILs) is increasing with a very fast rate because of their beneficial properties such as undetectable vapor pressure, non-inflammability, wide liquid range, reusability and high thermal stability [6-9].

Moerover, heterocycles, an important class of organic compounds, constitute more than $70 \%$ of promising bioactive and drug molecules presently available in literature [10]. Among these widespread heterocyclic compounds, nitrogen heterocycles occupy a distinct position because of their wide natural abundance and their applications as biologically active pharmaceuticals, agrochemicals, and functional materials are becoming more and more important [11-13]. Among them, the indole ring system is probably the most well-known heterocycle, a common and important feature of various natural products and medicinal agents [14]. It constitutes the core of spiro-oxindoles, a recurring subclass of indole alkaloids in nature which exhibits highly pronounced biological activities, thus deserving to occupy a unique place among pharmacological agents [15]. Similarly, heterocycles containing the pyrazole, phthalazine and urazole moieties played a crucial role in the history of heterocyclic chemistry and have been used as important pharmacores and synthons in the field of organic chemistry and drug designing [16]. In particular, they are used as antibacterial, antifungal, antiviral, antiphrastic and insecticidal agents [17-23]. Upon these salient aspects, incorporation of the two pharmacophoric, pyrazole and oxindole, motiffing into a single molecule via efficient and environmentally benign synthetic methods would be beneficial [24].

Encouraged by these observation and in continuation of our earlier studies on the synthesis of spirooxindole heterocyclic compounds and the use of ionic liquid as catalyst in organic synthesis,[30-33] we report, herein, the synthesis of novel spiro[pyrazole-triazole] and known derivatives of spiro[pyrazole-phthalazine] under catalysis of the ionic liquid.

\section{Experimental}

Matreials and methodes 
All chemicals were purchased from Merck or Fluka Chemical Companies. All known compounds were identified by comparison of their melting points and spectral data with those reported in the literature. Progress of the reactions was monitored by thin layer chromatography (TLC) using silica gel SIL G/UV 254 plates. IR spectra were recorded using a Shimadzu IR- 470 spectrometer with $\mathrm{KBr}$ plates. ${ }^{1} \mathrm{H}$ NMR and ${ }^{13} \mathrm{C}$ NMR spectra were recorded on a Bruker Avance-400 MHz spectrometer.

General procedure

A mixture of isatin deivatives $\mathbf{1 a - e}(1 \mathrm{mmol})$ malononitrile/ ethyl cyano-acetate $\mathbf{2 a - b}(1 \mathrm{mmol})$ and 4-phenylurazole/ phthalhydrazide $3 \mathbf{a}-\mathbf{b}$ (1 mmol) was added to a vial containing a magnetic stirring bar and $(1 \mathrm{~mL})$ of the ionic liquid [BMIm] Cl. The reaction mixture was sealed and stirred at $90{ }^{\circ} \mathrm{C}$ until the disappearance of the starting materials (Table 1). At this stage, the products due to poor solubility in the ionic liquid appeared as a precipitate. In order to extract the ionic liquid, after completion of the reaction, the residue was washed with $(2 \times 10 \mathrm{~mL})$ water. Washing the solid residue with ethanol $(10 \mathrm{~mL}, 95.5 \%)$ has given remarkably pure powders of product 4a-k. The ionic liquid was recovered from the aqueous extracts by evaporating water under reduced pressure and reused in the next cycles (Scheme 4).

The selected spectral data

7-Amino-6-carbonitrile-1,2,3,5,2',3'-hexahydro-1,3,2'-trioxo-2-phenyl spiro[pyrazolo[1,2 a] $[1,2,4]$ triazole-5,3'-indole (4a)

Red solid, yield $0.33 \mathrm{~g}$, 90\%, IR (KBr) ( $\left.v_{\max } / \mathrm{cm}^{-1}\right): 3438,3330,1748,1702,1662,1527$, and 1650. ${ }^{1} \mathrm{H}$ NMR (400 MHz, DMSO): $\delta 6.91(1 \mathrm{H}, \mathrm{d}, J=8.0 \mathrm{~Hz}), 7.06(1 \mathrm{H}, \mathrm{t}, J=7.6 \mathrm{~Hz}), 7.36-7.41(1 \mathrm{H}, \mathrm{m})$, 7.44-7.49 (5H, m), 7.51 (2H, s, NH $), 7.56-7.60(1 \mathrm{H}, \mathrm{m}), 10.96(1 \mathrm{H}, \mathrm{s}, \mathrm{NH}) .{ }^{13} \mathrm{C}$ NMR (100 MHz, DMSO): $\delta$ 59.3, 71.5, 112.7, 118.3, 123.2, 125.2, 126.5 (3C), 128.1, 129.3 (3C), 132.4, 138.8, 151.2, 153.9, 159.8, 184.9. Anal. Calcd. for $\mathrm{C}_{19} \mathrm{H}_{12} \mathrm{~N}_{6} \mathrm{O}_{3}$ : C, 61.29; H, 3.25; N, 22.57; Found: C, 61.10; H, 3.12; N, 22.19.

7-Amino-5'-boromo-6-carbonitrile-1,2,3,5,2',3'-hexahydro-1,3,2'-trioxo-2-phenyl spiro[pyrazolo[1,2a][1,2,4]triazole-5,3'-indole (4b)

Yellow solid, yield $0.37 \mathrm{~g}$, 84\%, IR (KBr) $\left(v_{\max } / \mathrm{cm}^{-1}\right): 3357,3248,3193,2206,1763,1705$, and 1659. ${ }^{1} \mathrm{H}$ NMR (400 MHz, DMSO): $\delta 6.90(1 \mathrm{H}, \mathrm{d}, J=8.4 \mathrm{~Hz}$ ), 7.49 (1H, d.d.d, $J=2.0 \mathrm{HZ}, 1.6 \mathrm{~Hz}, 6.4 \mathrm{~Hz}$ ), $7.83(1 \mathrm{H}, \mathrm{d}, J=1.6 \mathrm{~Hz}), 8.0-8.03(3 \mathrm{H}, \mathrm{m}), 8.04-8.08(2 \mathrm{H}, \mathrm{m}), 8.30-8.32(1 \mathrm{H}, \mathrm{m}), 8.40\left(2 \mathrm{H}, \mathrm{s}, \mathrm{NH}_{2}\right)$, $11.10(1 \mathrm{H}, \mathrm{s}, \mathrm{NH}) .{ }^{13} \mathrm{C}$ NMR (100 MHz, DMSO): $\delta 59.9,69.9,112.7,114.7,127.5,128.0,128.1,128.2$, 
128.3, 129.3, 134.9, 135.5, 136.1, 136.9, 141.9, 152.4, 152.9, 156.8, 172.6. Anal. Calcd. for $\mathrm{C}_{19} \mathrm{H}_{11} \mathrm{BrN}_{6} \mathrm{O}_{3}: \mathrm{C}, 50.57 ; \mathrm{H}, 2.46 ; \mathrm{N}, 18.62$; Found: $\mathrm{C}, 50.18 ; \mathrm{H}, 2.32 ; \mathrm{N} 18.51$.

Ethyle-7-amino -6-carbonitrile-1,2,3,5,2',3'-hexahydro-1,3,2'-trioxo-2-phenyl-spiro[pyrazolo[1,2a][1,2,4]triazole-5,3'-indole]-6-carboxylate (4c)

White solid, $0.38 \mathrm{~g}$, 91\%, IR (KBr) $\left(v_{\max } / \mathrm{cm}^{-1}\right): 3470,3350,2983,1784,1724$, and 1622. ${ }^{1} \mathrm{H}$ NMR (400 MHz, DMSO): $\delta 0.86(3 \mathrm{H}, \mathrm{t}, J=6.8 \mathrm{~Hz}), 3.84(2 \mathrm{H}, \mathrm{q}, J=6.4 \mathrm{~Hz}), 6.85(1 \mathrm{H}, \mathrm{d}, J=7.6 \mathrm{~Hz}), 7.00(1 \mathrm{H}$, t, $J=7.2 \mathrm{~Hz}), 7.27(1 \mathrm{H}, \mathrm{t}, J=7.6 \mathrm{~Hz}), 7.40-7.43(4 \mathrm{H}, \mathrm{m}), 7.53(2 \mathrm{H}, \mathrm{d}, J=7.6 \mathrm{~Hz}), 7.55\left(2 \mathrm{H}, \mathrm{s}, \mathrm{NH}_{2}\right)$, 10.76 (1H, s, NH). ${ }^{13} \mathrm{C}$ NMR (100 MHz, DMSO): $\delta$ 14.2, 59.1, 71.2, 83.0, 110.4, 122.6, 125.1, 127.1, 127.6, 129.5, 129.7, 130.5, 130.9, 143.3, 149.2, 151.1, 163.6, 173.9. Anal. Calcd. for $\mathrm{C}_{21} \mathrm{H}_{17} \mathrm{~N}_{5} \mathrm{O}_{5}$ : C, 60.14; H, 4.09; N, 16.70; Found: C, 60.01; H, 4.11; N, 16.23.

Ethyle-7-amino-5'-chloro -6-carbonitrile-1,2,3,5,2',3'-hexahydro-1,3,2'-trioxo-2-phenylspiro[pyrazolo[1,2-a][1,2,4]triazole-5,3'-indole]-6-carboxylate (4d)

White solid, $0.41 \mathrm{~g}, 90 \%$, IR (KBr) $\left(v_{\max } / \mathrm{cm}^{-1}\right): 3476,3364,1788,1752,1727$, and 1681. ${ }^{1} \mathrm{H}$ NMR (400 MHz, DMSO): $\delta 0.89(3 \mathrm{H}, \mathrm{t}, J=7.6 \mathrm{~Hz}), 3.87(2 \mathrm{H}, \mathrm{q}, J=6.8 \mathrm{~Hz}), 6.86(1 \mathrm{H}, \mathrm{d}, J=8.0 \mathrm{~Hz}), 7.32(1 \mathrm{H}$, d, $J=8.0 \mathrm{~Hz}), 7.43-7.48(3 \mathrm{H}, \mathrm{m}), 7.53(2 \mathrm{H}, \mathrm{d}, J=7.6 \mathrm{~Hz}), 7.57\left(2 \mathrm{H}, \mathrm{s}, \mathrm{NH}_{2}\right), 7.69(1 \mathrm{H}, \mathrm{s}), 10.88(1 \mathrm{H}, \mathrm{s}$, NH) ppm. ${ }^{13} \mathrm{C}$ NMR (100 MHz, DMSO): $\delta$ 14.3, 59.2, 71.3, 83.2, 111.8, 125.7, 126.6, 127.1, 129.2, $129.4,129.7,130.4,131.0,142.2,149.0,150.5,163.5,173.9$. Anal. Calcd. for $\mathrm{C}_{21} \mathrm{H}_{16} \mathrm{ClN}_{5} \mathrm{O}_{5}$ : C, 55.58; H, 3.55; N, 15.43; Found: C, 55.51; H, 3.49; N, 15.25 .

3'-Amino-2,5',10'-trioxo-5',10'-dihydrospiro[indoline-3,1'-pyrazolo[1,2-b]phthalazine]-2'-carbonitrile (4e)

Yellow solid, 0.32g, 90\%, IR (KBr) ( $\left.v_{\max } / \mathrm{cm}^{-1}\right): 3349,3301,3248,2212,1754,1704$, and 1600. 1H NMR (400 MHz, DMSO): $\delta 0.93(1 \mathrm{H}, \mathrm{d}, J=8.0 \mathrm{~Hz}), 7.01(1 \mathrm{H}, \mathrm{t}, J=7.6 \mathrm{~Hz}), 7.31(1 \mathrm{H}, \mathrm{t}, J=7.6 \mathrm{~Hz})$, $7.48(1 \mathrm{H}, \mathrm{d}, J=7.6 \mathrm{~Hz}), 7.98-8.02(2 \mathrm{H}, \mathrm{m}), 8.03-8.07(1 \mathrm{H}, \mathrm{m}), 8.36\left(2 \mathrm{H}, \mathrm{s}, \mathrm{NH}_{2}\right), 10.96(1 \mathrm{H}, \mathrm{s}, \mathrm{NH})$.

3'-Amino-5-methyl-2,5',10'-trioxo-5',10'-dihydrospiro[indoline-3,1'-pyrazolo[1,2-b]phthalazine]-2'carbonitrile (4f)

Yellow solid, $0.33 \mathrm{~g}$, 88\%, IR (KBr) $\left(v_{\max } / \mathrm{cm}^{-1}\right): 3378,3300,3026,2201,1726,1710$, and 1660. ${ }^{1} \mathrm{H}$ NMR (400 MHz, DMSO): $\delta 3.67\left(3 \mathrm{H}, \mathrm{s}, \mathrm{CH}_{3}\right), 6.84(1 \mathrm{H}, \mathrm{d}, J=8.4 \mathrm{~Hz}), 6.86(1 \mathrm{H}, \mathrm{d} . \mathrm{d}, J=2.4 \mathrm{~Hz}, J=$ $2.4 \mathrm{~Hz}$ ), $7.22(1 \mathrm{H}, \mathrm{d}, J=2.4 \mathrm{~Hz}), 7.99-8.04(2 \mathrm{H}, \mathrm{m}), 8.06-8.08(1 \mathrm{H}, \mathrm{m}), 8.35\left(2 \mathrm{H}, \mathrm{s}, \mathrm{NH}_{2}\right), 10.76(1 \mathrm{H}, \mathrm{s}$, $\mathrm{NH})$. 
3'-Amino-5-bromo-2,5',10'-trioxo-5',10'-dihydrospiro[indoline-3,1'-pyrazolo[1,2-b]phthalazine]-2'carbonitrile $(\mathbf{4 g})$

Yellow solid, $0.37 \mathrm{~g}$, 86\%, IR (KBr) $\left(v_{\max } / \mathrm{cm}^{-1}\right): 3356,3248,3022,2206,1763,1705$, and 1659. ${ }^{1} \mathrm{H}$ NMR (400 MHz, DMSO): $\delta 0.90(1 \mathrm{H}, \mathrm{d}, J=8.4 \mathrm{~Hz}), 7.49(1 \mathrm{H}, \mathrm{d} . \mathrm{d}, J=2.0 \mathrm{~Hz}, J=2.0 \mathrm{~Hz}), 7.83(1 \mathrm{H}, \mathrm{d}$, $J=1.6 \mathrm{~Hz}), 8.00-8.03(2 \mathrm{H}, \mathrm{m}), 8.05-8.08(1 \mathrm{H}, \mathrm{m}), 8.39\left(2 \mathrm{H}, \mathrm{s}, \mathrm{NH}_{2}\right), 11.09(1 \mathrm{H}, \mathrm{s}, \mathrm{NH})$.

3'-Amino-5-chloro-2,5',10'-trioxo-5',10'-dihydrospiro[indoline-3,1'-pyrazolo[1,2-b]phthalazine]-2'carbonitrile (4h)

Yellow solid, 0.35g, 90\%, IR (KBr) ( $\left.v_{\max } / \mathrm{cm}^{-1}\right): 3354,3247,3192,2207,1763,1704$, and 1658. ${ }^{1} \mathrm{H}$ NMR (400 MHz, DMSO): $\delta 0.95(1 \mathrm{H}, \mathrm{d}, J=8.4 \mathrm{~Hz}), 7.36(1 \mathrm{H}, \mathrm{d} . \mathrm{d}, J=2.4 \mathrm{~Hz}, J=2.4 \mathrm{~Hz}), 7.71(1 \mathrm{H}, \mathrm{d}, J$ $=2.0 \mathrm{~Hz}), 8.00-8.03(2 \mathrm{H}, \mathrm{m}), 8.06-8.08(1 \mathrm{H}, \mathrm{m}), 8.39\left(2 \mathrm{H}, \mathrm{s}, \mathrm{NH}_{2}\right), 11.08(1 \mathrm{H}, \mathrm{s}, \mathrm{NH})$.

Ethyl 3'-amino-5-bromo-2,5',10'-trioxo-5',10'-dihydrospiro[indoline-3,1'-pyrazolo[1,2-b]phthalazine]2 '-carboxylate(4i)

Yellow solid, $0.36 \mathrm{~g}$, 89\%, IR (KBr) $\left(v_{\max } / \mathrm{cm}^{-1}\right): 3435,3324,2892,1733,1715$, and $1672 .{ }^{1} \mathrm{H}$ NMR (400 MHz, DMSO): $\delta 0.88$ (3h, t, $J=6.8 \mathrm{~Hz}$ ), $3.86(2 \mathrm{H}, \mathrm{q}, J=7.2 \mathrm{~Hz}), 6.93(1 \mathrm{H}, \mathrm{d}, J=8.0 \mathrm{~Hz}$ ), 7.30(1H, d, $J=7.6 \mathrm{~Hz}), 7.87-7.91(2 \mathrm{H}, \mathrm{m}), 7.99-8.03(2 \mathrm{H}, \mathrm{m}), 8.05-8.07(1 \mathrm{H}, \mathrm{m}), 8.80-8.32(1 \mathrm{H}, \mathrm{m})$, $10.75(1 \mathrm{H}, \mathrm{s}, \mathrm{NH}), 11.55\left(2 \mathrm{H}, \mathrm{s}, \mathrm{NH}_{2}\right)$.

\section{Results and discussion}

With this background in mind and in line with our interest in the synthesis of spiro compounds [30-35], we report an efficient and environmentally benign protocol for the synthesis of pyrazole motifs compounds by condensation of isatin derivatives 1a-e, malononitrile/ ethyl cyano-acetate $\mathbf{2 a - b}$ and 4-phenylurazole/ phthalhydrazide $\mathbf{3 a - b}$ catalyzed by ionic liquid [BMIm] $\mathrm{Cl}$ and without using any solvent or additional catalyst. The products were obtained in high yields by a simple work-up (Scheme 1). At the onset of the study, an equimolar mixture of the model substrates; isatin 1a, malononitrile 2a, and 4- phenylurazole 3a was treated with the selected ionic liquids without any added catalyst and solvent (Scheme 2).

The results are shown in Table 1, a short range of $\mathrm{pH}$ conditions associated with the selected ionic liquids to investigate the effect of acidity or basicity of these media on the reaction performance. As can be seen (Table 1), the condensation was performed in different ionic liquids, but the efficiency and the yield of the reaction in weak basic ionic liquid [BMIm] Cl were higher than in other ionic liquids, thereby making [BMIm] Cl the most suitable reaction medium for successive reactions (Table 1). The results show that Brønsted acid-base ionic liquids such as TMGT and 
$\mathrm{TMGT}_{\mathrm{f}}$ lead to the products in low yields and the reaction time is longer than neutral ionic liquid $[\mathrm{BMIm}] \mathrm{BF}_{4}$. The acidic ionic liquid, $\left[\mathrm{BMIm} \mathrm{HSO}_{4}\right.$, was not as effective as [BMIm]Cl. The result showed that different ILs exhibit a dramatic difference in the yield of $\mathbf{4 a}$, attributed to the tunable physical properties of ionic liquids.

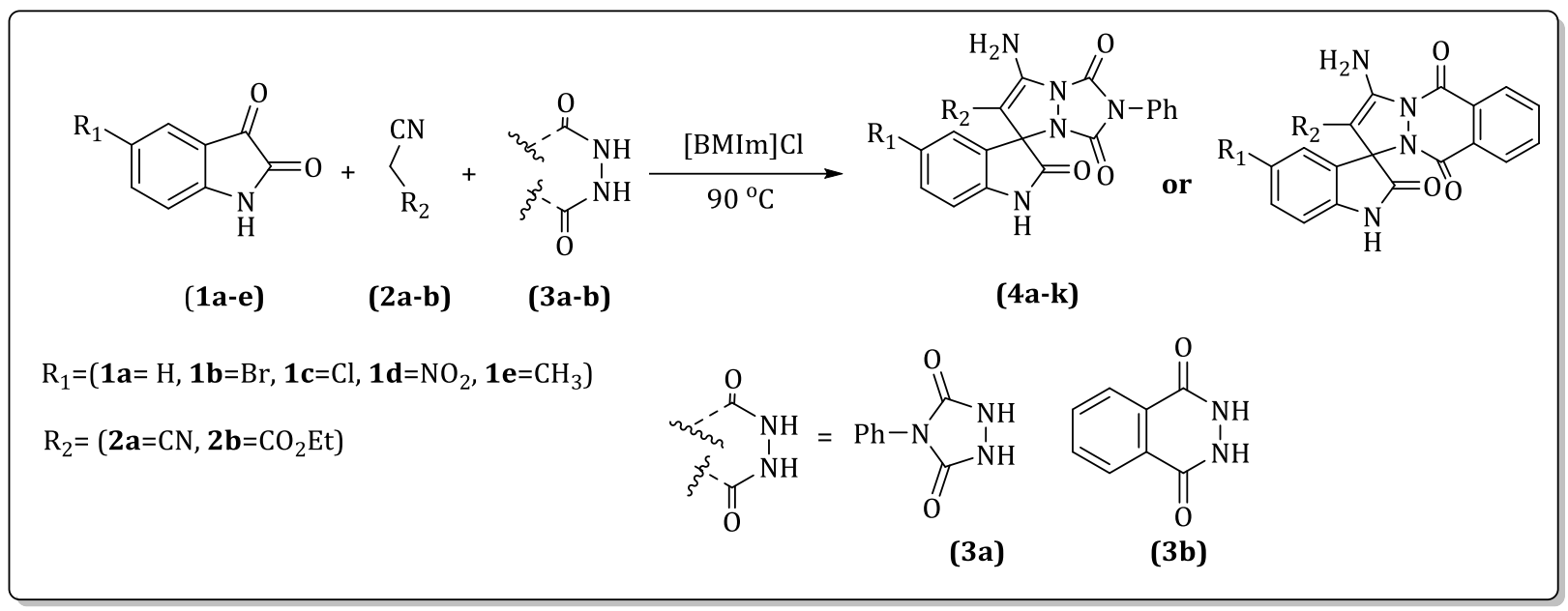

Scheme 1. Reaction protocol for the synthesis of spirooxindoles compounds<smiles></smiles><smiles>N#CC1=C(N)N2C(=O)N(c3ccccc3)C(=O)C12C1(O)Nc2ccccc21</smiles>

3a

$4 a$

Scheme 2. The model reaction

Table 1. Optimization of reaction conditions ${ }^{\mathrm{a}}$

$\begin{array}{ccccc}\text { Entry } & \text { Catalyst } & \text { Conditions } & \text { Time(min) } & \text { Yield(\%) }^{\mathrm{b}} \\ 1 & - & \text { Solvent-free }\left(90^{\circ} \mathrm{C}\right) & 180 & - \\ 2 & p-\mathrm{TSA} & \text { EtOH (reflux) } & 180 & - \\ 3 & \mathrm{FeCl}_{3} & \text { EtOH (reflux) } & 180 & - \\ 4 & \mathrm{ZnCl}_{2} & \text { EtOH (reflux) } & 180 & \text { - } \\ 5 & \mathrm{DABCO} & \text { EtOH (reflux) } & 180 & \text { Trace } \\ 6 & {[\mathrm{BMIm}] \mathrm{Cl}} & \text { Solvent-free }\left(40^{\circ} \mathrm{C}\right) & 180 & \text { Intermediate } 5 \\ 7 & {[\mathrm{BMIm}] \mathrm{Cl}} & \text { Solvent-free }\left(90^{\circ} \mathrm{C}\right) & 40 & 90 \\ 8 & {[\mathrm{BMIm}] \mathrm{BF}_{4}} & \text { Solvent-free }\left(90^{\circ} \mathrm{C}\right) & 300 & 21 \\ 9 & {[\mathrm{BMIm}] \mathrm{HSO}_{4}} & \text { Solvent-free }\left(90^{\circ} \mathrm{C}\right) & 240 & - \\ 10 & \mathrm{TMGT} & \text { Solvent-free }\left(90^{\circ} \mathrm{C}\right) & 300 & 10\end{array}$




\begin{tabular}{lcccc}
11 & TMGT $_{\mathrm{f}}$ & Solvent-free $\left(90^{\circ} \mathrm{C}\right)$ & 240 & 10 \\
12 & {$[\mathrm{BMIm}] \mathrm{LiCl}$} & Solvent-free $\left(90^{\circ} \mathrm{C}\right)$ & 240 & 18 \\
13 & {$[\mathrm{BMIm}] \mathrm{Cl}$} & EtOH (reflux) & 90 & 48 \\
\hline
\end{tabular}

a Reaction conditions: isatin ( $1 \mathrm{mmol})$, malononitrile $(1 \mathrm{mmol})$, 4-phenylurazole (1mmol) and catalyst (1 mmol) or ionic liquid (1 ml)

${ }^{\mathrm{b}}$ Isolated yields

In order to show the merit of the catalyst, we have compared the obtained results in the synthesis spiro[pyrazole-phthalazine] catalyzed by $[\mathrm{BMIm}] \mathrm{Cl}$, with some hetrogeneous and homogeneous catalysts, as reported in the literature (Table 2). The harsh reaction conditions, longer reaction times and irresability of other methods make our system a better choice [25-29].

After detecting [BMIm] $\mathrm{Cl}$ as the more efficient catalyst solvent, we examined the method with a range of substrates to determine the reaction specificity and scope. Consequently, various substituted isatins (1a-e) were used to react with malononitrile (2a) or ethyl cyano-acetate (2b) and 4-phenylurazole (3a) phthalhydrazide (3b) was treated with the selected ionic liquid under the optimized conditions (Table 1). These results are compiled in Table 2. As shown in Table 3, in all cases, the reaction gives the products good yields and prevents problems associated with solvent usage such as cost, handling, safety and pollution.

A plausible mechanism for the formation of the selected product $4 \mathrm{a}-\mathrm{k}$ in the presence of [BMIm]Cl ionic liquid as a catalyst solvent is outlined in (Scheme 3). The condensation of isatin 1ae, malononitrile/ ethyl cyano-acetate $\mathbf{2} \mathbf{a}-\mathbf{b}$ and compound 3a-b may occur by a mechanism of Knoevenagel condensation, Michael addition, intramolecular cyclization, and isomerization. Initially, intermediate $\mathbf{5}$ is formed by Knoevenagel condensation of isatin 1a-e and malononitrile/ ethyl cyano-acetate $\mathbf{2} \mathbf{a}-\mathbf{b}$ by the action of ionic liquid. Then, the proton of compound $\mathbf{3 a - b}$ is attacked by intermediate 5 to form intermediate $\mathbf{6}$. Michael addition of intermediate $\mathbf{6}$ on $\mathbf{5}$ leads to the formation of $\mathbf{7}$, followed by cyclization and isomerization, affording the corresponding products 4a-k (Scheme 3).

Table 2. Comparision of $[\mathrm{BMIm}] \mathrm{Cl}$ with other catalysts for the synthesis of $3^{\prime}$-Amino-2,5',10'trioxo-5',10'-dihydrospiro[indoline-3,1'-pyrazolo[1,2-b]phthalazine]-2'-carbonitrile

$\begin{array}{ccccc}\text { Entry } & \text { Catalyst and Conditions } & \text { Reaction time (min) } & \text { Yield(\%) } & \text { [Ref.] } \\ 1 & \mathrm{CH}_{3} \mathrm{CN} / \text { piperidine/ reflux } & 240 & 80 & {[28]} \\ 2 & \text { EtOH/ L-proline/ reflux } & 120 & 90 & {[29]} \\ 3 & {[\mathrm{DBU}][\mathrm{AcOH}] / 100^{\circ} \mathrm{C}} & 60 & 90 & {[26]} \\ 4 & \text { PEG-600/ NiCl } / 100^{\circ} \mathrm{C} & 60 & 90 & {[25]} \\ 5 & \text { EtOH/ piperidine/ sonication/ r.t } & 30 & 90 & {[27]}\end{array}$




\begin{tabular}{ccccc}
6 & EtOH/ piperidine/ reflux & 240 & 78 & [27] \\
7 & {$[\mathrm{BMIm}] \mathrm{Cl} / \mathrm{Neat} / 90^{\circ} \mathrm{C}$} & 40 & 90 & This work \\
\hline
\end{tabular}

Table 3. Syntesis of spirooxindoles derivatives $\mathbf{4 a - k}$ in the presence of [BMIm] Cl

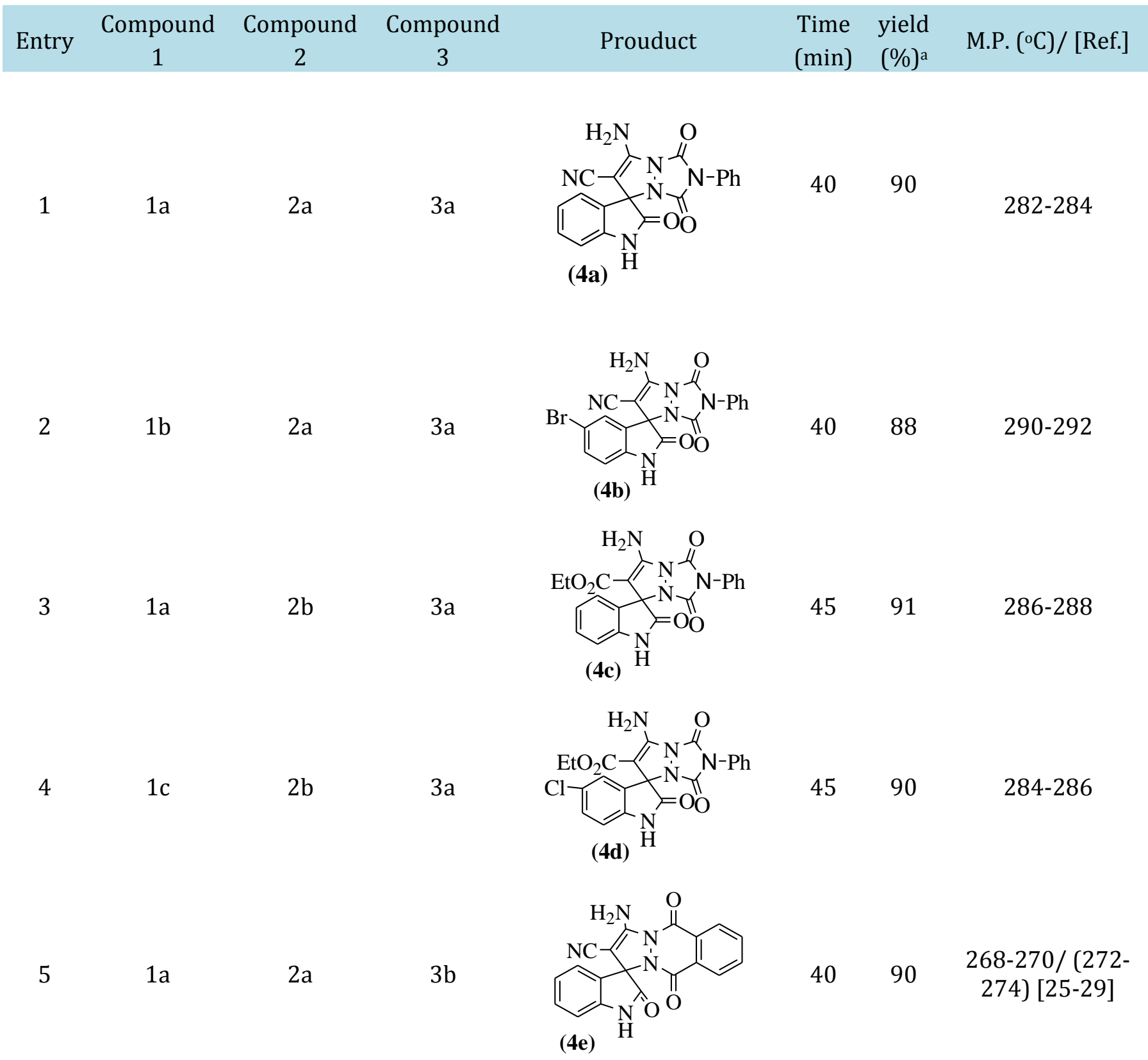


$621 \mathrm{a}$

(4h)

$92 \mathrm{a} 2 \mathrm{~b} \quad 3 \mathrm{~b}$

(4i)

$10 \quad 1 b$

$2 b$

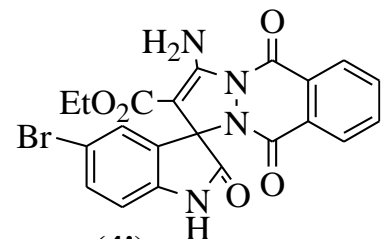

$40 \quad 87$

331-333/ (328-

$3 b$

(4j)

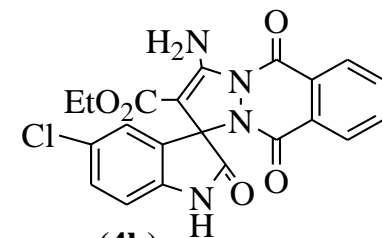

40

90

332-334/ (330332) [25-27]

(4k)

The structures of the new compounds 4 a-d were confirmed by $\mathrm{IR},{ }^{1} \mathrm{H},{ }^{13} \mathrm{C}$ NMR and CHN as well as mass spectral data. For example, the IR spectrum of $\mathbf{4 a}$ showed distinct absorptions at 3435, 3324 , and 1733, $1672 \mathrm{~cm}^{-1}$ corresponding to vibrations of its $\mathrm{NH}$ and $\mathrm{CO}$ groups. A relatively wide range of chemical shifts, $\delta 6.85-7.60 \mathrm{ppm}$, was observed for the aromatic protons of this product, and the presence of two broad singlets at 10.96 and $7.51 \mathrm{ppm}$ with a 1:2 ratios was detected, 
attributed to $\mathrm{NH}$ and $\mathrm{NH}_{2}$, respectively. The ${ }^{13} \mathrm{C}$ NMR spectrum of 4 a showed 19 distinct resonances in agreement with the proposed structure. The characteristic signal due to the spiro carbon displayed at $\delta 59.3$.

In the next phase of the study, the viability of catalysis in the recycled ionic liquid in model reaction was evaluated. After completion of the reaction, the ionic liquid was washed using water, evaporated under reduced pressure and then subjected to the next run with the same substrates and the same reaction time. Figure 1 displays similar high conversions obtained after consecutive recycling of the ionic liquid.

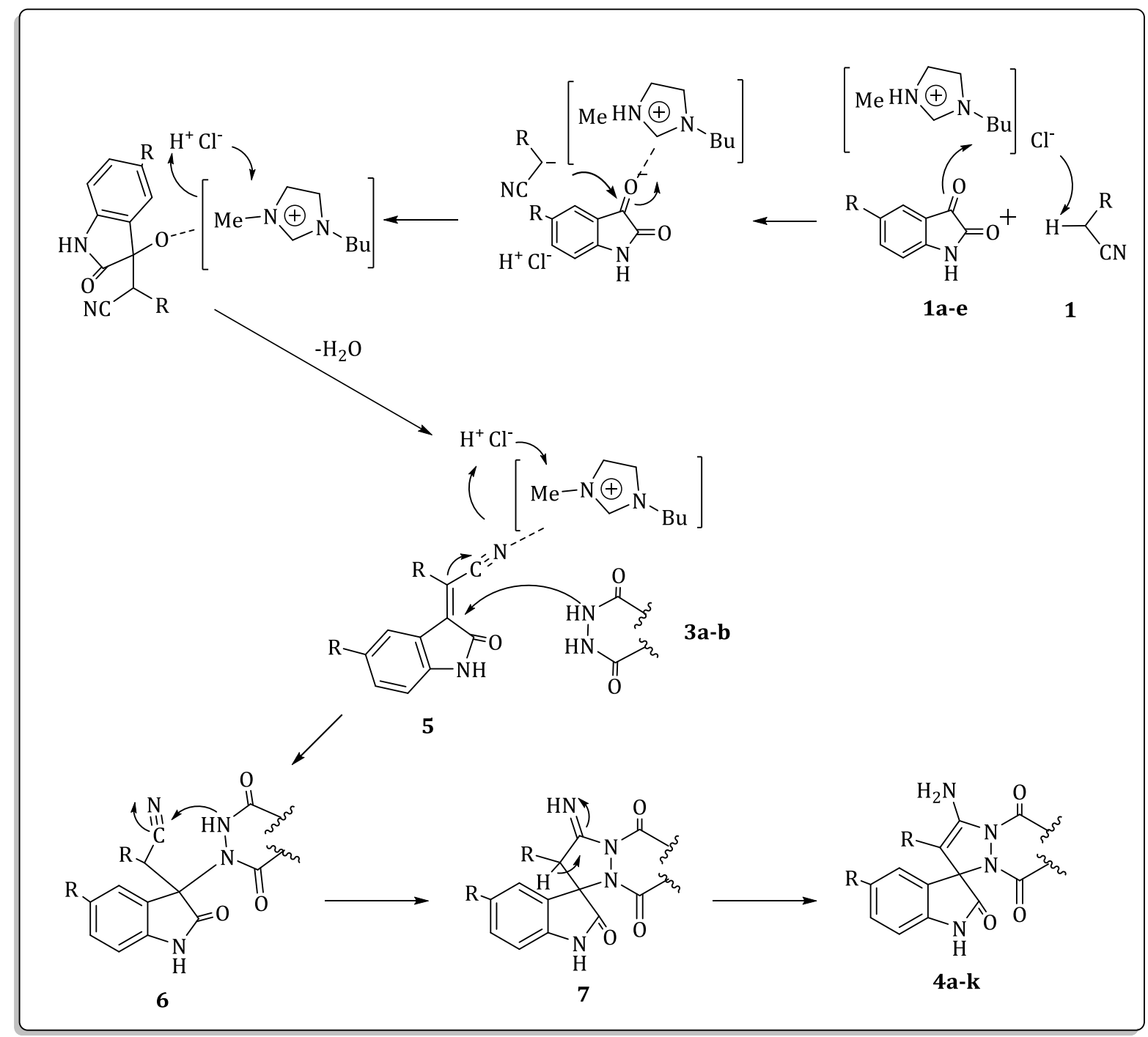

Scheme 3. Possible mechanism for synthesis of spirooxindole systems $4 \mathbf{a}-\mathbf{k}$ in the presence of [BMIm]Cl as a catalyst

\section{Conclusion}


In summary, an efficient method for synthesis of spiro-annulated pyrazole- oxindole ring system by using simple and readily available starting materials under catalysis of the ionic liquid, [BMIm]Cl, was introduced here. The ionic liquid plays the role of catalyst solvent and can be recovered to be reused several times. Another advantage of the present method is that; it requirs no metal catalysts or additional solvent proceeding with appropriate rate with respect to the methods that gave similar skeletone. This method not only affords the products in excellent yield but also avoids the problems associated with catalyst cost and pollution. We expect this method to find extensive applications in the field of combinatorial chemistry, diversity-oriented synthesis, and drug discovery.

Figure 1. Recyclability of $[\mathrm{BMIm}] \mathrm{Cl}$

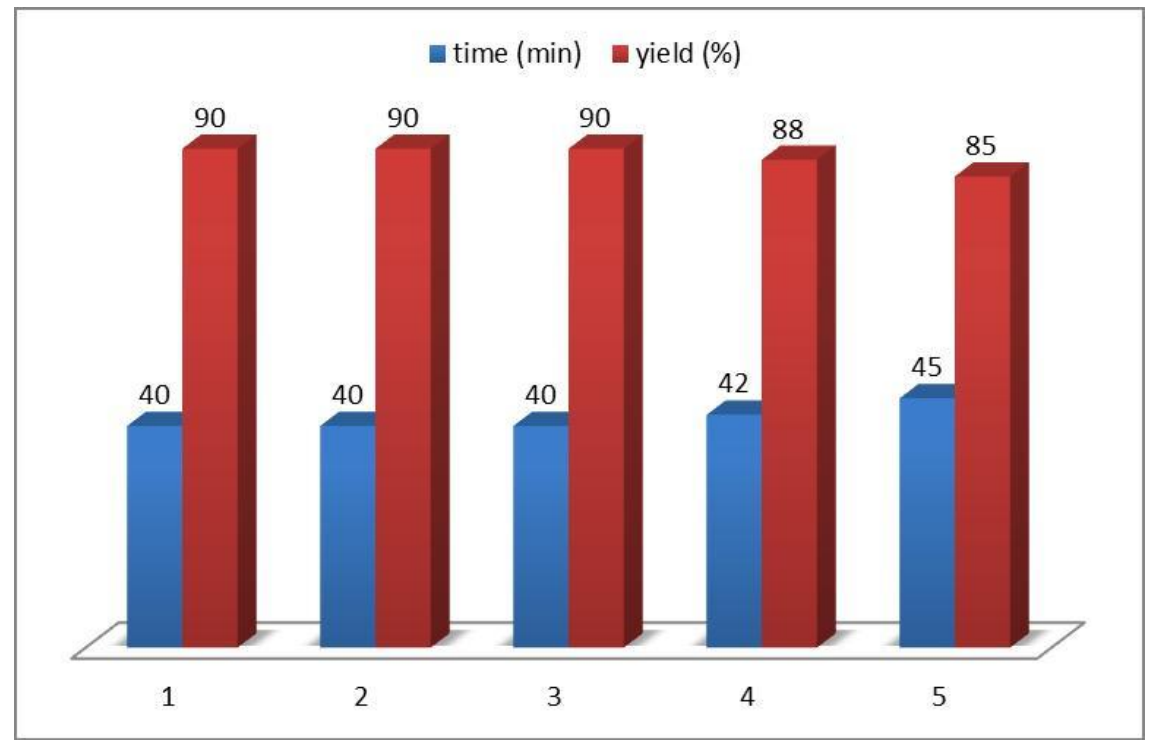

\section{Acknowledgments}

gratefully acknowledge the financial support from the Research Council of University of Islamic Azad University, Tehran Medicnal Science Branch.

\section{References}

[1]. Trost B.M. Science, 1991, 254:1471

[2]. Bienayme H., Hulme C., Oddon G., Schmidt P. Chem. Eur. J., 2000, 6: 3321

[3]. Orru R.V.A., Greef M.D. Synthesis, 2003, 10:1471

[4] Von Wangelin A.J., Neumann H., GÖrdes D., Klaus S., Strubing D., Beller M., Chem. Eur .J., 2003, 9: 4286

[5]. Martins M.A.P., Frizzo C.P., Moreira D,N., Zanatta N., Bonacorso H., Chem Rev., 2008, 108:2015 
[6]. Fremantle M., Chem. Eng. News, 1998, 76:32

[7]. Yadav J.S., Reddy B.V.S., Baishya G., Reddy K.V., Narsaiah A.V., Tetrahedron, 2005, 61:9541

[8]. Mi X., Luo S., He J., Cheng J.P, Tetrahedron Lett., 2004, 45:4413

[9]. Legeay J.C., Vanden Eynde J.J., Bazureau J.P. Tetrahedron, 2005, 61:12386

[10]. Jiang B., Rajale T., Wever W., Tu S.J., Li G., Chem. Asian. J., 2010, 5:2318

[11]. Frranklin E.C., Chem. Rev., 1935, 16:305

[12]. Bergstorm F.W., Chem. Rev., 1944, 35:77

[13]. Lichtenthaler F.W., Acc. Chem. Rea., 2002, 135:728

[14]. Hoalihan W.J., Remers W.A., Brown R.K., Indoles: Part 1; Wiley: New Yourk, NY, 1992.

[15]. Ma J., Hecht S.M., Chem. Commun., 2004, 1190.

[16]. Edmondson S., Danishefsky S.J., Sepp-Lorenzinol L., Rosen N.J. Am. Chem. Soc., 1999, 121:2147

[17]. Smith W.P., Sollis L.S., Howes D.P., Cherry C.P., Starkay D.I., Cobley N.K., J. Med. Chem., 1998, 41:787

[18]. El-hashash M., Soliman A., Elshamy I. Turk. J. Chem., 2012, 36:347

[19]. Genin M., Biles C., Keiser B., Poppe S., Swaney S., Tarpley W., Yagi Y., Romero D., J. Med. Chem., $2000,43: 1034$

[20]. Abdel-Rahman A., Abdel-Megied A., Hawata M., Kasem E., Shabaan M. Monatsh Chem., 2007, 138:889

[21]. Sharshira E., Hamada N. Molecules, 2011, 16:7736

[22]. Rashad A., Hegab M., Abdel-Megeid R.J., Micky J., Abdel-Megeid F. Bioorg. Med. Chem., 2008, 16:7102

[23]. Kalirajan R., Sivakumar S., Jubie S., Gowramma B., Suresh B. Int J. Chem. Tech Res., 2009, 1:27 [24]. Wasserscheid P., Welton T., Ionic Liquids in Synthesis; Wiley-VCH Verlag: Stuttgart, Germany, 2002.

[25]. Zhang X.N., Li Y.X., Zhang Z.H. Tetrahedron, 2011, 67:7426

[26]. Kumari K., Sing R., Singh K.N. Ind. J. Chem., 2014, 53B:625

[27]. Wang J., Bai X., Xu C., Wang Y., Lin W., Zou Y., Shi D. Molecules, 2012, 17:8694

[28]. Chen H., Shi D.Q, J. Het. Chem., 2013, 50:56

[29]. Shantui G., Perumal P.T., J. Chem. Sci., 2010, 122:415

[30]. Rad-Moghadam K., Youseftabar-Miri L. Tetrahedron, 2011, 67:5693

[31]. Rad-Moghadam K., Youseftabar-Miri L., J. Florin. Chemistry, 2012, 135:213

[32]. Hosseinjani-Pirdehi H., Rad-Moghadam K., Youseftabar-Miri L., Tetrahedron, 2014, 70:1780

[33]. Youseftabar-Miri L., Rafieirad M., IJC, 2014, 1:15 
[34]. Rad-Moghadam K., Youseftabar-Miri L. Arkivoc, 2011, xi:43

[35]. Rad-Moghadam K., Youseftabar-Miri L. Synlett, 2011, 13:43

How to cite this manuscript: Leila Youseftabar-Miri*, Hamide Hosseinjani-Pirdehi. An efficient approach to the synthesis of some novel heterocycles related to indoline moiety using [BMIm] Cl catalysis. Asian Journal of Green Chemistry, 2017, 1, 56-68. DOI: 10.22631/ajgc.2017.95721.1017 